\title{
Free Radical Scavenging Activity of Ethanolic Extracts from Herbs and Spices Commercialized in Brazil
}

\author{
Lilian Regina Barros Mariutti, Gisela Pizarro de Mattos Barreto, Neura Bragagnolo and \\ Adriana Zerlotti Mercadante ${ }^{1 *}$ \\ ${ }^{1}$ Departamento de Ciência de Alimentos; Faculdade de Engenharia de Alimentos; Universidade Estadual de \\ Campinas C.P.: 6121; azm@fea.unicamp.br; 13083-862; Campinas - SP - Brasil
}

\begin{abstract}
Ethanolic extracts from 23 different dried herbs and spices commercialized in Brazil were investigated for their free radical scavenging properties using the stable free radicals 2,2'-diphenyl- $\beta$-picrylhydrazyl ( $\left.D P P H^{*}\right)$ and 2,2'-azinobis(3-ethylbenzothiazoline-6-sulphonic acid) $\left(A B T S^{\circ+}\right)$, and Trolox as reference (TEAC) for both radicals. The kinetic curves for both radicals showed to follow the first order kinetics model and the decay rate constant $\left(k_{\text {obs }}\right)$ was calculated. For all the samples, the two methods showed a good linear TEAC correlation, indicating that the average reactivity of the compounds present in the ethanolic extracts was similar. Sage and rosemary extracts showed the highest free radical scavenging capacities, while onion showed negligible activity and colorifico, one of the most consumed spices in Brazil, showed low ABTS ${ }^{\circ+}$ scavenging activity. Three distinct situations were found for the extracts concerning the DPPH scavenging capacities: (1) extracts, like rosemary and laurel, that presented the same efficient concentrations $\left(E C_{50}\right)$ but differed in the TEAC values and velocities of action $\left(k_{o b s}\right)$, (2) extracts, such as garlic and basil, that showed similar EC 50 and TEAC values, but different $k_{\text {obs }}$ values and (3) extracts that reacted at the same velocities but completely differed in the free radical scavenging capacities, like black pepper, savory, nutmeg, rosemary and sage. Similar considerations could be done for the ABTS ${ }^{\circ+}$ results. For the first time the $A_{B T S^{\circ+}}$ scavenging activity for allspice, basil, cardamom, chives, colorifico, cumin, dill, laurel, marjoram, parsley and tarragon was reported.
\end{abstract}

Key words: antioxidant activity; free radical scavenging activity; DPPH; ABTS; herbs; spices; colorifico

\section{INTRODUCTION}

In the past years, the consumer preference for natural products increased, and as a consequence, the interest in searching for new antioxidants sources, in particular aromatic herbs and spices, also increased. Furthermore, herbs and spices have been utilized since antiquity for their culinary qualities and they also served as natural food preservatives to prevent deterioration of food quality that occurred during the processing and storage, mainly due to oxidative processes, resulting in losses of color and nutritional value, development of off-flavors, changes in texture and in the general appearance.

In recent studies, the antioxidant activity of some spices and herbs using radical scavenging methods, in particular 2, 2'-diphenyl- $\beta$ picrylhydrazyl $\left(\mathrm{DPPH}^{\circ}\right)$ and 2, 2'-azino-bis(3-

\footnotetext{
Author for correspondence
} 
ethylbenzothiazoline-6-sulphonic acid) $\left(\mathrm{ABTS}^{\circ+}\right)$, have been investigated. However, different solvents were employed to obtain the extracts, making it difficult to compare the antioxidant activity values amongst the studies. In addition, the results of the $\mathrm{DPPH}^{\bullet}$ scavenging were given in different unities, such as \% activity (Cervato et al., 2000), \% activity in relation to control (Capecka et al., 2005), \% activity related to caffeic acid (Exarchou et al., 2002) or to pyrogallol (Nuutila et al., 2003), $\mathrm{IC}_{50}$ or $\mathrm{EC}_{50}$ (Dorman et al., 2004; Hinneburg et al., 2006; Kosar et al., 2005). Most of the results obtained with the ABTS radical has been reported as Trolox equivalent antioxidant capacity (TEAC) (Dorman et al., 2003; Dorman and Hiltunen, 2004; Murcia et al., 2004; Tsai et al., 2005), although ascorbic acid equivalent has also been used (Chun et al., 2005). Conflicting results regarding the free radical scavenging activity are also found in the literature. Using $\mathrm{DPPH}^{\circ}$, the extract of dried oregano obtained with methanol/water (8:2) showed $83 \%$ activity (Capecka et al., 2005), similar to $80 \%$ of activity obtained for both aqueous and methanolic extracts of this spice (Cervato et al., 2000). On the other hand, ethanolic and acetonic extracts also from oregano showed, respectively, 99 and $54 \%$ activity (Exarchou et al., 2002). The methanol extracts from dried red spring onion showed higher radical scavenging activity than that of dried garlic (Nuutila et al., 2003), but Miller et al. (2000) reported higher activity of fresh garlic extracts than those of fresh onion.

There are few studies concerning the $\mathrm{ABTS}^{\circ+}$ scavenging capacity of spices and herbs extracts. Murcia et al. (2004) found that the aqueous extracts from nutmeg and ginger presented TEAC values higher than BHT. Tsai et al. (2005) found that the ginger aqueous extract showed higher antioxidant activity than those from garlic and onion. On the other hand, garlic and onion methanolic extracts showed reasonable antioxidant capacity compared to other vegetables (Chun et al., 2005).

Both $\mathrm{DPPH}^{\bullet}$ and $\mathrm{ABTS}^{\bullet+}$ radical tests were carried out for few herbs and spices extracts. Deodourized aqueous extracts from rosemary and sage were the two most active extracts against the radicals $\mathrm{DPPH}^{\bullet}$ and $\mathrm{ABTS}^{\circ+}$, followed by oregano and thyme (Dorman et al., 2003). Fresh garlic from three different countries showed similar results for the antioxidant activity using $\mathrm{DPPH}^{\bullet}$ and $\mathrm{ABTS}^{\circ+}$ assays (Gorinstein et al., 2005).

The aim of the present study was to examine the free radical scavenging activity of 23 worldwide used herbs and spices commercialized in Brazil. In addition, a comparison between the $\mathrm{DPPH}^{\circ}$ and $\mathrm{ABTS}^{\circ+}$ results was carried out for most samples. Colorifico (mixture of corn flour and annatto powder), one of the spices most used in Brazil, was also investigated since to the best of our knowledge, there were no reports concerning the $\mathrm{DPPH}^{*}$ and $\mathrm{ABTS}^{*+}$ scavenging capacity of colorifico. There were no reports available on antioxidant properties using the radical $\mathrm{ABTS}^{\circ+}$ for allspice, basil, cardamom, chives, colorifico, cumin, dill, laurel, marjoram, parsley, and tarragon.

\section{MATERIALS AND METHODS}

\section{Materials}

The following dried plant materials were obtained at the Central Municipal Market in São Paulo city, Brazil: allspice (Pimenta dioica), basil (Ocimum basillicum), black pepper (Piper nigrum), caraway (Carum cari), cardamom (Elettaria cardamomum), chives (Allium shoenoprasum), colorifico, coriander (Coriandrum sativum), cumin (Carum carvi), dill (Anethum graveolens), garlic (Allium sativum), ginger (Zingiber officinale), laurel (Laurum nobilis), marjoram (Majorana hortensis), nutmeg (Myristica fragans), onion (Allium cepa), oregano (Origanum vulgaris), parsley (Petroselium crispum), sage (Salvia officinalis), savory (Satureja hortensis), rosemary (Rosmarinus officinalis), tarragon (Artemisia dracundulus) and thyme (Thymus vulgaris). The radicals (DPPH, ABTS), Trolox and potassium persulfate were purchased from Sigma-Aldrich. All solvents were of analytical grade.

\section{Preparation of the extracts}

Before extraction, all the dried spices and herbs were ground in an electric coffee grinder (Eastern Electric, CM 180) for 20 seconds. Five grams of each sample were extracted with $50 \mathrm{~mL}$ ethanol on a table shaker at $120 \mathrm{rpm}$ for $15 \mathrm{~h}$. Then the extract was filtered, and the residue was reextracted with $20 \mathrm{~mL}$ ethanol for $3 \mathrm{~h}$. The filtrates were combined and the very fine particles that 
eventual remained were separated by centrifugation at $3000 \mathrm{rpm}$ for 20 minutes. The crude extracts were diluted using ethanol according to the assay needs.

\section{ABTS radical cation decolorization assay}

The free radical scavenging activity of the ethanolic extracts was carried out based on a method developed by Re et al. (1999), with few modifications. Since the maximum absorption wavelength of the radical was observed at $750 \mathrm{~nm}$, the absorbance of the extracts and standard reactions were measured at $750 \mathrm{~nm}$, instead of 734 $\mathrm{nm}$, as did Re at al. (1999). The decrease in the absorbance was determined at room temperature after $0,6,12,18,24$ and $30 \mathrm{~min}$, and every 10 minutes thereafter until the reaction reached the steady state or until the absorbance decreased less than $10 \%$ compared to the last reading, in order to obtain the kinetic curves of the antioxidant activity of all samples and for the standard Trolox. The activities of the sample extracts were calculated through the range of the dose-response curve of Trolox according to equation 1 , and expressed as Trolox equivalent antioxidant capacity (TEAC).

Inhibition of $A_{750 \mathrm{~nm}}(\%)=\left(1-\mathrm{A}_{\mathrm{f}} / \mathrm{A}_{\mathrm{o}}\right) \times 100$ (eq. 1$)$

where $A_{o}$ is the absorbance of the uninhibited radical cation and $A_{f}$ is the absorbance measured 30 minutes after addition of the sample extracts or 6 minutes after addition of Trolox solution. In addition, using the TEAC values, the rate constant $\left(k_{\text {obs }}\right)$ was calculated according to the first-order kinetic model. All reactions were performed in triplicate.

\section{DPPH radical assay}

The radical scavenging capacities of each ethanolic extract in different concentrations were estimated according to the method of BrandWillians et al. (1995). Different aliquots of the sample extracts were added to $3 \mathrm{~mL}$ of a $6 \times 10^{-5}$ $\mathrm{mol} / \mathrm{L} \mathrm{DPPH}{ }^{\bullet}$ methanolic solution. The decrease in absorbance at room temperature was determined at $515 \mathrm{~nm}$ after $0,6,12,18,24$ and $30 \mathrm{~min}$ and every 10 minutes thereafter until the reaction reached the steady state or until the absorbance declined less than $10 \%$ of the last reading. The TEAC values of different extract aliquots were plotted in order to obtain the kinetic curves. The efficient concentration $\left(\mathrm{EC}_{50}=\mathrm{g}\right.$ spice $\left./ \mathrm{Kg} \mathrm{DPPH}^{\circ}\right)$ was determined as the amount of ethanolic spice extract necessary to decrease the initial $\mathrm{DPPH}^{\circ}$ concentration by $50 \%$. In order to compare the results obtained by the $\mathrm{DPPH}^{\circ}$ and $\mathrm{ABTS}^{\circ+}$ assays, TEAC values were calculated based on the percentage of its inhibition at the steady state. These values were also used to calculate the firstorder rate constant $\left(k_{\mathrm{obs}}\right)$. All reactions were carried out in triplicate.

\section{Statistical analysis and kinetic calculations}

Statistica for Windows - release 5.0 (StatSoft Inc., Tulsa, USA ) was used for the analysis of variance (ANOVA) and significant differences amongst the herbs and spices were classified by LSD $(\mathrm{p}<0.05)$. This program was also employed to estimate the correlation between the $\mathrm{DPPH}^{\bullet}$ and $\mathrm{ABTS}^{\circ+}$ assays and the correlation between the $k_{\text {obs }}$ values, both by simple linear regression.

The software Microcal Origin 5.0 (Microcal Origin Software Inc., Northampton, USA) was used for kinetic analysis. The TEAC value was plotted against time (min) and a linear regression analysis was used to determine the adequacy of the kinetic model. The rate constant $\left(k_{\text {obs }}\right)$ was determined from the first-derivative of the curves plotted (eq. 2).

$$
\mathrm{TEAC}=\mathrm{TEAC}_{0} \times \exp \left(-k_{\mathrm{obs}} \times \mathrm{t}\right)
$$

\section{RESULTS AND DISCUSSION}

The capability of the ethanolic spice and herbs extracts to scavenge both radicals, $\mathrm{DPPH}^{\bullet}$ and $\mathrm{ABTS}^{\circ+}$, and their first-order rate constants $\left(k_{\text {obs }}\right)$ are shown in Table $1 . \mathrm{DPPH}^{\circ}$ assay was not performed for chives, colorifico and parsley extracts because they showed high absorbance at $515 \mathrm{~nm}$, interfering with the measurement. All curves (Fig. 1) for both radicals showed to follow the first order kinetics model $\left(0.83 \leq \mathrm{R}^{2} \leq 0.99\right.$, $\mathrm{p}$ $<0.002)$. 

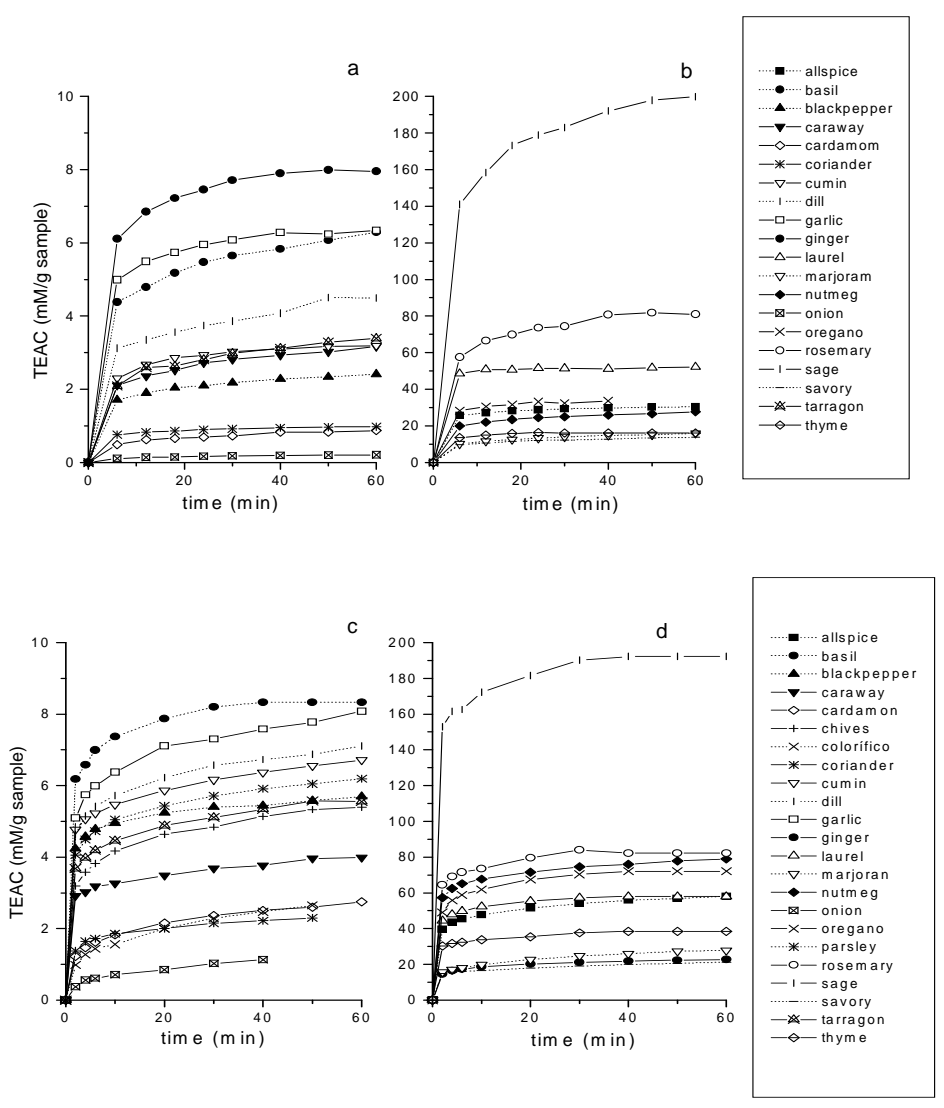

Figure 1 - The kinetic first-order curves obtained for the reaction of the extracts with DPPH ${ }^{\bullet}(\mathbf{a}$, b) and $\mathrm{ABTS}^{\bullet+}(\mathbf{c}, \mathbf{d})$.

According to Table 1, the following performance order of the extracts analyzed by $\mathrm{DPPH}^{\circ}$, expressed as $\mathrm{EC}_{50}$, was sage $>$ rosemary $=$ laurel $>$ thyme $>$ allspice $>$ oregano $>$ nutmeg $>$ marjoram $>$ savory $>$ ginger $>$ garlic $>$ basil $>$ tarragon $>$ dill $=$ cumin $>$ caraway $>$ black pepper $>$ coriander $>$ cardamom $>$ onion. Concerning $\mathrm{DPPH}^{\bullet}$ expressed as TEAC, there were some changes in the ranking order, oregano presented a free radical scavenging capacity equal to thyme, and dill was better antioxidant than tarragon and cumin. The extracts presented the following order obtained by the $\mathrm{ABTS}^{\bullet+}$ decoloration assay: sage $>$ rosemary $=$ nutmeg $\geq$ oregano $>$ allspice $=$ laurel $>$ thyme $=$ marjoram $=$ ginger $>$ savory $>$ garlic $\geq$ basil $\geq$ dill $=$ parsley $\geq$ cumin $=$ black pepper $=$ tarragon $>$ chives $>$ caraway $>$ colorifico $>$ cardamom $>$ coriander $>$ onion.

The same ranking order for the free radical scavenging activity measured by the $\mathrm{DPPH}^{\bullet}$ test was found by Kosar et al. (2005) for sage, rosemary, thyme, oregano, savory and basil. In addition, the same order as found in the present work was reported by Dorman et al. (2003) for aqueous extracts in the $\mathrm{ABTS}^{\circ+}$ assay: sage > oregano $>$ rosemary $>$ thyme. On the other hand, rosemary and oregano extracts obtained with different solvents presented higher $\mathrm{DPPH}^{\circ}$ scavenging activity than sage (Exarchou et al., 2002; Dorman et al., 2003; Bertelli et al., 2004).

Colorifico showed lower TEAC value (2.64) when compared to the other herbs and spices analyzed in this study. Since bixin was found to be the major carotenoid in colorifico (Mercadante, 2001; Tocchini and Mercadante, 2001), this value could be compared to other studies where similar ABTS $^{\circ+}$ TEAC values for some carotenoids were found, like lycopene (2.5 and 2.9), $\beta$-carotene (1.4 and 1.9), $\alpha$-carotene (1.9 and 1.3) and $\beta$ cryptoxanthin (2.0) (Bohm et al., 2002; Miller et al., 1996). 
Table 1 - Antioxidant activity of spices and herbs, determined by DPPH ${ }^{\bullet}$ and ABTS $^{\bullet+}$ assays.

\begin{tabular}{|c|c|c|c|c|c|}
\hline \multirow{2}{*}{ Herbs and Spices } & \multicolumn{3}{|c|}{ DPPH $^{\circ}$} & \multicolumn{2}{|l|}{ ABTS $^{\bullet+}$} \\
\hline & $\mathrm{EC}_{50}$ (g spice /Kg DPPH') & TEAC (mM/g spice) & $k_{\text {obs }}\left(\min ^{-1}\right)$ & TEAC (mM/g spice) & $k_{\text {obs }}\left(\min ^{-1}\right)$ \\
\hline Allspice & $8.3 \pm 0.1^{\mathrm{m}}$ & $30.4 \pm 0.2^{\mathrm{e}}$ & 0.27 & $57.0 \pm 0.3^{\mathrm{d}}$ & 0.36 \\
\hline Basil & $43.0 \pm 0.2^{\mathrm{h}}$ & $6.5 \pm 0.6^{\mathrm{j}}$ & 0.13 & $8.6 \pm 0.5^{\mathrm{g}, \mathrm{h}}$ & 0.47 \\
\hline Black Pepper & $110 \pm 2^{\mathrm{d}}$ & $2.5 \pm 0.1^{\mathrm{n}}$ & 0.14 & $5.7 \pm 0.2^{\mathrm{j}}$ & 0.50 \\
\hline Caraway & $89 \pm 2^{\mathrm{e}}$ & $2.8 \pm 0.0^{\mathrm{m}}$ & 0.11 & $3.9 \pm 0.1^{1}$ & 0.41 \\
\hline Cardamom & $463 \pm 12^{b}$ & $0.8 \pm 0.0^{\mathrm{p}}$ & 0.09 & $2.3 \pm 0.1^{\mathrm{n}}$ & 0.10 \\
\hline Chives & - & - & - & $4.97 \pm 0.02^{\mathrm{k}}$ & 0.24 \\
\hline Colorífico & - & - & - & $2.64 \pm 0.06^{\mathrm{m}}$ & 0.08 \\
\hline Coriander & $235 \pm 5^{c}$ & $1.1 \pm 0.0^{\circ}$ & 0.20 & $2.21 \pm 0.07^{\circ}$ & 0.28 \\
\hline Cumin & $81 \pm 3^{\mathrm{e}, \mathrm{f}}$ & $3.2 \pm 0.1^{1}$ & 0.17 & $6.0 \pm 0.3^{\mathrm{i}, \mathrm{j}}$ & 0.38 \\
\hline Dill & $75 \pm 1^{\mathrm{f}}$ & $4.4 \pm 0.1^{\mathrm{k}}$ & 0.11 & $6.9 \pm 0.4^{\mathrm{h}, \mathrm{i}}$ & 0.31 \\
\hline Garlic & $41 \pm 1^{\mathrm{h}}$ & $6.7 \pm 0.3^{\mathrm{j}}$ & 0.22 & $8.5 \pm 0.2^{g}$ & 0.28 \\
\hline Ginger & $19.1 \pm 0.3^{\mathrm{i}}$ & $7.8 \pm 0.1^{\mathrm{i}}$ & 0.20 & $23.0 \pm 0.3^{\mathrm{e}}$ & 0.31 \\
\hline Laurel & $3.9 \pm 0.2^{\circ}$ & $53 \pm 2^{c}$ & 0.43 & $57 \pm 3^{\mathrm{d}}$ & 0.56 \\
\hline Majoram & $17.84 \pm 0.08^{\mathrm{j}}$ & $14.8 \pm 0.4^{\mathrm{g}}$ & 0.10 & $25 \pm 1^{\mathrm{e}}$ & 0.14 \\
\hline Nutmeg & $9.6 \pm 0.2^{\mathrm{k}}$ & $27.0 \pm 0.6^{\mathrm{f}}$ & 0.15 & $77 \pm 1^{\mathrm{b}, \mathrm{c}}$ & 0.46 \\
\hline Onion & $2224 \pm 29^{a}$ & $0.20 \pm 0.01^{\mathrm{q}}$ & 0.08 & $0.89 \pm 0.05^{\mathrm{p}}$ & 0.09 \\
\hline Oregano & $8.4 \pm 0.1^{1}$ & $33.5 \pm 0.3^{\mathrm{d}}$ & 0.28 & $73.3 \pm 0.9^{c}$ & 0.41 \\
\hline Parsley & - & - & - & $6.2 \pm 0.1^{\mathrm{i}}$ & 0.32 \\
\hline Rosemary & $3.86 \pm 0.06^{\circ}$ & $83 \pm 7^{b}$ & 0.15 & $89 \pm 5^{b}$ & 0.56 \\
\hline Sage & $1.65 \pm 0.00^{\mathrm{p}}$ & $192 \pm 8^{\mathrm{a}}$ & 0.15 & $202 \pm 10^{\mathrm{a}}$ & 0.62 \\
\hline Savory & $20.3 \pm 0.4^{\mathrm{i}}$ & $13.5 \pm 0.2^{\mathrm{h}}$ & 0.14 & $20.4 \pm 0.5^{\mathrm{f}}$ & 0.31 \\
\hline Tarragon & $62.4 \pm 2.4^{\mathrm{g}}$ & $3.34 \pm 0.05^{1}$ & 0.10 & $5.6 \pm 0.1^{\mathrm{j}}$ & 0.30 \\
\hline Thyme & $6.4 \pm 0.3^{\mathrm{n}}$ & $33 \pm 1^{\mathrm{d}}$ & 0.27 & $38 \pm 1^{\mathrm{e}}$ & 0.58 \\
\hline
\end{tabular}

-, not measured.

Data are expressed as average \pm standard deviation of three experiments.

Different letters in the same column means that the average is significantly different $(p<0.05)$.

EC50 is efficient concentration.

The TEAC and $\mathrm{EC}_{50}$ values gave information regarding the quality and reactivity, indicating the amount of radical scavenger compounds present in each sample. The decay rate constant $\left(k_{\text {obs }}\right)$ was related to the reaction time, and thus low $k_{\text {obs }}$ value indicated a slow action antioxidant, while high values of $k_{\text {obs }}$ indicated a fast action one.

Considering the parameters $\mathrm{EC}_{50}$, TEAC and $k_{\mathrm{obs}}$ obtained by the $\mathrm{DPPH}^{\bullet}$ assay, three different situations were found. First, rosemary and laurel extracts presented the same $\mathrm{EC}_{50}$ values (3.86 and 3.85 , respectively) but their TEAC and $k_{\mathrm{obs}}$ values were different, meaning that the same amount of rosemary and laurel was necessary to decrease the initial $\mathrm{DPPH}^{\bullet}$ concentration to $50 \%$, although the rosemary extract showed higher activity than that of laurel, as compared to Trolox. On the other hand, the rosemary extract could be considered a slow action free radical scavenger compared to the laurel extract. Explanations for this behavior could be probably due to different compounds responsible for the antioxidant activity (Shan et al., 2005; Skerget et al., 2005). Second, garlic and basil showed the same $\mathrm{EC}_{50}$ and TEAC values but the $k_{\text {obs }}$ obtained for garlic (0.22) was higher than that for basil (0.13). This meant that the same amount of both herbs was able to decrease $50 \%$ of the initial $\mathrm{DPPH}^{\circ}$ level; furthermore the free radical scavenging qualities of the compounds present in both extracts were also similar. However, the garlic extract could be considered a free radical scavenger of fast action. It is well known that garlic has organosulfur compounds as the main responsible substances of its antioxidant activity (Nuutila et al., 2003), whereas in basil the antioxidant activity is mainly due to phenolic compounds (Shan et al., 2005). Finally, black pepper, savory, nutmeg, rosemary and sage presented the same $k_{\text {obs }}$ values but different $\mathrm{EC}_{50}$ and TEAC values. This meant that all of them reacted at the same rate and reached the steady state at almost the same time; however, they showed different free radical scavenging capacities. Among the samples of this group, black pepper showed the lowest free radical scavenging capacity while sage the highest one. 
Similar consideration could be done from the ABTS $^{\circ+}$ data (Table 1). For example, dill and parsley presented similar $k_{\mathrm{obs}}$ and TEAC values, indicating that these spices showed similar reactivity and free radical scavenging activity. On the other hand, caraway, oregano, basil and nutmeg had the same reaction rates $\left(k_{\text {obs }}\right)$ but oregano and nutmeg showed much higher free radical scavenging activity than caraway and basil. The efficiency of the added antioxidants depends, besides the structural features, on many other factors such as concentration, temperature, light, type of substrate, and physical state of the system. The importance of evaluating the reaction rate is related to the way these spices should be added as antioxidants to protect food products, e. g. either for a long period of storage or during processing. For example, an antioxidant of slow action, like basil, should be added to frozen stored products and an antioxidant of fast action, like garlic, should be used in baked or fried products.

A high linear correlation $\left(\mathrm{R}^{2}=0.97, \mathrm{p}<0.0001\right)$ was achieved between the TEAC results obtained by the $\mathrm{ABTS}^{\circ+}$ and $\mathrm{DPPH}^{\bullet}$ assays for the spices tested (Fig. 2a). This indicated that the average reactivity of the compounds present in the different extracts towards both radicals could be considered similar.

The decay rate constant $\left(k_{\mathrm{obs}}\right)$ presented a tendency of higher values for $\mathrm{ABTS}^{\circ+}$ than for $\mathrm{DPPH}^{\circ}$ assays, suggesting that, in average, the compounds present in the ethanolic extracts reacted faster with $\mathrm{ABTS}^{\circ+}$ radicals. Since these radicals showed different reactivity (Huang et al., 2005; Roginsky and Lissi, 2005), it was not expected a good correlation between the $k_{\text {obs }}$ values obtained by $\mathrm{DPPH}^{\circ}$ and $\mathrm{ABTS}^{\circ+}$ assays $\left(\mathrm{R}^{2}=0.46, \mathrm{p}=0.04\right)$ (Fig. 2b). For example, sage presented a clear difference when comparing the $k_{\text {obs }}$ values, 0.15 and 0.62 , for $\mathrm{DPPH}^{\circ}$ and $\mathrm{ABTS}^{\circ+}$ assays, respectively. In other words, the same extract of sage could act like a slow action or a fast action antioxidant depending on the radical assay applied. The same occurred for other spices as seen in Table 1 for basil, caraway, and rosemary among others.

In summary, the two radical scavenging assays gave similar antioxidant activity trends for the ethanolic extracts of all spices and herbs analyzed in this study. Since, free radical scavenger is an important mechanism for the inhibitory activity towards lipid peroxidation, and can be a good marker for antioxidant activity, the results indicate that the addition of some spices and herbs to food products can prevent their oxidative deterioration in foods.

\section{ACKNOWLEDGEMENT}

The authors thank the financial support of the Brazilian Agencies CAPES, CNPq and FAPESP.

\section{RESUMO}

Extratos etanólicos de 23 ervas e condimentos desidratados comercializados no Brasil foram analisados quanto as suas propriedades antioxidantes utilizando os radicais $2,2^{\prime}$-difenil- $\beta$ picrilhidrazil (DPPH ${ }^{\circ}$ ) e ácido 2,2'-azino-bis(3etilbenzotiazolina-6-sulfônico) $\left(\mathrm{ABTS}^{\bullet+}\right)$, Trolox foi usado como referência para ambos radicais. As curvas cinéticas seguiram o modelo cinético de primeira ordem, e a partir destas foram calculadas as constantes de velocidade de $\left(k_{o b s}\right)$. Os extratos de sálvia e de alecrim apresentaram as maiores capacidades redutoras de radicais livres, enquanto o extrato de cebola praticamente não apresentou atividade e o colorífico, um dos condimentos mais consumidos no Brasil, apresentou baixa atividade de aprisionamento de radicaisABTS ${ }^{\circ+}$. Três situações distintas foram observadas em relação à capacidade de aprisionar radicais $\mathrm{DPPH}^{\circ}$ : (1) extratos, como os de alecrim e de louro, que apresentaram as mesmas concentrações eficientes $\left(\mathrm{EC}_{50}\right)$, porém, valores de TEAC e velocidade de ação $\left(\mathrm{k}_{\mathrm{obs}}\right)$ distintos ; (2) extratos, como os de alho e de manjericão, que apresentaram valores similares de $\mathrm{EC}_{50}$ e TEAC, com valores distintos de $k_{\text {obs }}$ e (3) extratos com a mesma velocidade de ação que diferiram totalmente na capacidade de aprisionamento de radicais livres, como de pimenta preta, segurelha, noz moscada, alecrim e sálvia. Considerações semelhantes podem ser feitas para os resultados de $\mathrm{ABTS}^{\circ+}$. Osdois métodos apresentaram boa correlação de TEAC, indicando que a reatividade dos compostos presentes nos extratos etanólicos foi similar. A atividade redutora de $\mathrm{ABTS}^{\circ+}$ para pimenta da Jamaica, manjericão, cardamomo, cebolinha, colorífico, cominho, dill, louro, manjerona, salsinha e estragão foi reportada pela primeira vez. 


\section{REFERENCES}

Bertelli, D., Plessi, M. and Miglietta, F. (2004), Effect of industrial microwave treatment on the antioxidant activity of herbs and spices. Italian Journal of Food Science, 1, 97-103.

Bohm, V., Puspitasari-Nienaber, N. L., Ferruzzi, M. G. and Schwartz, S. J. (2002), Trolox equivalent antioxidant capacity of different geometrical isomers of $\alpha$-carotene, $\beta$-carotene, lycopene and zeaxanthin. Journal of Agricultural and Food Chemistry, 50, 221226.

Brand-Williams, W., Cuvelier, M. E. and Berset, C. (1995), Use of a free radical method to evaluate antioxidant activity. Lebensmittel Wissenschaft und Technologie, 28, 25-30.

Capecka, E., Mareczek, A. and Leja, M. (2005), Antioxidant activity of fresh and dry herbs of some Lamiaceae species. Food Chemistry, 93, 223-226.

Cervato, G., Carabelli, M., Gervasio, S., Cittera, A., Cazzola, R. and Cestaro, B. (2000), Antioxidant properties of oregano (Origanum vulgare) leaf extracts. Journal of Food Biochemistry, 24, 453-465.

Chun, O. K., Kim, D. O., Smith, N., Schroeder, D., Han, J. T. and Lee, C. Y. (2005), Daily consumption of phenolics and total antioxidant capacity from fruits and vegetables in the American diet. Journal of the Science of Food and Agriculture, 85, 1715-1724.

Dorman, H. J. D., Peltoketo, A., Hiltunen, R. and Tikkanen, M. J. (2003), Characterization of the antioxidant properties of de-odourised aqueous extracts from selected Lamiaceae herbs. Food Chemistry, 83, 255-262.

Dorman, H. J. D., Bachmayer, O., Kosar, M. and Hiltunen, R. (2004), Antioxidant properties of aqueous extracts from selected Lamiaceae species grown in Turkey. Journal of Agricultural and Food Chemistry, 52, 762-770.

Dorman, H. J. D. and Hiltunen, R. (2004), Fe(III) reductive and free radical-scavenging properties of summer savory (Satureja hortensis L.) extract and subfractions. Food Chemistry, 88, 193-199.

Exarchou, V., Nenadis, N., Tsimidou, M., Gerothanassis, I. P., Troganis, A. and Boskou, D. (2002), Antioxidant activities and phenolic composition of extracts from Greek oregano, Greek sage and summer savory. Journal of Agricultural and Food Chemistry, 50, 5294-5299.
Gorinstein, S., Drzewiecki, J., Leontowicz, J., Leontowicz, M., Najman, K., Jastrzebski, Z., Zachwieja, Z., Barton, H., Shtabsky, B., Katrich, E. and Trakhtenberg, S. (2005), Comparison of the bioactive compounds and antioxidant potentials of fresh and cooked Polish, Ukrainian, and Israeli garlic. Journal of Agricultural and Food Chemistry, 53, 2726-2732.

Hinneburg, I., Dorman, H. J. D. and Hiltunen, R. (2006), Antioxidant activities of extracts from selected culinary herbs and spices. Food Chemistry, 97, 122-129.

Huang, D., Ou, B., Prior, R. L. (2005) The Chemistry behind antioxidant capacity assays. Journal of Agricultural and Food Chemistry, 53, 1841-1856.

Kosar, M., Dorman, H. J. D. and Hiltunen, R. (2005), Effect of an acid treatment on the phytochemical and antioxidant characteristics of extracts from selected Lamiaceae species. Food Chemistry, 91, 525-533.

Mascarenhas, J. M. O. and Toledo, M. C. F. (1999), Potential intake of annatto extracts in Brazil. Book of Abstracts of the Institute of Food Technologists Annual Meeting, Chicago, USA.

Mercadante, A. Z. (2001), Composition of Carotenoids from Annatto. In-Chemistry and Physiology of Selected Food Colorants, ed. Ames, J. M. and Hofmann, T. F., ACS Symposium Series 775, Washington, pp. 92-101.

Miller, N. J., Sampson, J., Candeias, L. P., Bramley, P. M. A. and Rice-Evans, C. A. (1996), Antioxidant activity of carotenes and xanthophylls. Federation of European Biochemical Societies Letters, 38, 4240242.

Miller, H. E., Rigelhof, F., Marquart, L., Prakash, A. and Kanter, M. (2000), Antioxidant content of whole grain breakfast cereals, fruits and vegetables. Journal of the American College of Nutrition, 19, 312S-319S.

Murcia, M. A., Egea, I., Romojaro, F., Parras, P., Jiménez, A. M. and Martínez-Tomé, M. (2004), Antioxidant evaluation in dessert spices compared with common food additives. Influence of irradiation procedure. Journal of Agricultural and Food Chemistry, 52, 1872-1881.

Nuutila, A. M., Puupponen-Pimiä, R., Aarni, M. and Oksman-Caldentey, K. M. (2003), Comparison of antioxidant activities of onion and garlic extracts by inhibition of lipid peroxidation and radical scavenging activity. Food Chemistry, 81, 485-493. 
Re, R., Pellegrini, N., Proteggente, A., Pannala, A., Yang, M. and Rice-Evans, C. (1999), Antioxidant activity applying an improved ABTS radical cation decolorization assay. Free Radical Biology and Medicine, 26, 1231-1237.

Roginsky, V.and Lissi, E. A. (2005) Review of methods to determine chain-breakingantioxidant activity in food. Food Chemistry, 92, 235-254.

Shan, B., Cai, Y. Z., Sun, M. and Corke, H. (2005), Antioxidant capacity of 26 spice extracts and characterization of their phenolic constituents. Journal of Agricultural and Food Chemistry, 53, 7749-7759.

Skerget, M., Kotnik, P., Hadolin, M., Hras, A. R., Simonic, M. and Knez, Z. (2005), Phenols, proanthocyanidins, flavones and flavonols in some plant materials and their antioxidant activities. Food Chemistry, 89, 191-198.

Tocchini, L. and Mercadante, A. Z. (2001), Extraction and determination of bixin and norbixin in annatto spice (colorifico). Ciência e Tecnologia de Alimentos, 21, 310-313.

Tsai, T. H., Tsai, P. J. and Ho, S. C. (2005), Antioxidant and anti-inflammatory activities of several commonly used spices. Journal of Food Science, 70, C93-C97.
Received: March 10, 2006; Revised: November 20, 2007;

Accepted: June 25, 2008. 